\title{
THE ANALYSIS OF TRUST AS AN ELEMENT OF SUPPORT TO DEMOCRATIC PROCESSES
}

\author{
UDC 316.658:342.5 \\ 316.334 .3 \\ 321.74
}

\author{
Žarko Đorić \\ University of Niš, Faculty of Economics, Niš, Serbia
}

\begin{abstract}
Declining trust is one of the central problems in modem politics. Trust declines in collective action arrangements. Trust is one of the "big questions," and "one of the normal obligations of political life." Embedded within it are fundamental issues of politics and democratic theory. This article discusses different conceptions of trust and its relations to democracy. The first part of the paper focuses on the conceptual and theoretical definition of trust. The second part provides an overview of one of the basic classifications of trust present in the contemporary literature. In the third part, the author discusses and provides appropriate argumentation on the relationship between trust and democracy.
\end{abstract}

Key words: trust, democracy, generalized trust, trust in political institutions

\section{INTRODUCTION}

As a multidimensional social phenomenon, embedded in socio-economic and cultural-historical conditions, trust affects the shaping of all aspects of social life and contributes to the stability of social relations (Leković, 2012: 65), which is undoubtedly of great importance for the democratic process itself.

In recent year, questions about trust and distrust have become prominent. Political psychology of trust involves ambivalent conceptual relations between demoracy and trust. The relationship between democracy and trust is such that it can be considered contradictory (Christensen, Laegreid, 2003: 7). "Democratic systems institutionalize distrust by providing many opportunities for citizens to oversee those empowered with the public trust. At the same time, trust is a generic social building block of collective action, and for this reason alone democracy cannot do without trust" (Warren et al., 1999: i).

Received January $24^{\text {th }}, 2019 /$ Accepted March $7^{\text {th }}, 2019$

Corresponding author: Žarko Đorić, PhD Student, Faculty of Economics, University of Niš, Republic of Serbia; E-mail: zdjoric82@gmail.com 
The importance and relevance of social capital is reflected in the strengthening of democratic stability, as a result that is normatively desirable for most people. According to the postulates of the theory of social capital, a decline in democratic support is a consequence of a decline of social trust (Newton, 2005: 4). On the other hand, trust as the atitudinal dimension of social capital plays a central role in strengthening the effectiveness of democratic governance (Seyd, 2016: 1). Particularly significant is the generalized trust, because democracy without generalized trust can lead to violence. For the same reason, the role of generalized trust in the process of constituting democracy, and in the development of a good society and good governance is indisputable. It is emphasized that generalized trust is a parameter for the evolution of moral standards in society. "Trust helps to build the social institutions of civil society upon which peaceful, stable and efficient democracy depends" (Zmerli, Newton, 2008: 707).

\section{THE CONCEPT AND THEORETICAL DEFINITIONS OF TRUST}

Taking into account that trust relationships are fundamental to the stability of democratic societies, trust has been the subject of considerable attention of social sciences in the last few decades. Economists often look to trust in the utilitarian sense: it functions as an "important lubricant in the social structure" and has the price as any other commodity (Arrow, 1974: 23, according to: Swedberg, 2006: 249); on the contrary, sociologists emphasize that trust has an independent quality which cannot be reduced to calculations and generating profits.

Trust is not easy to define, as evidenced by a vast number of books and articles on this concept (Newton, 2001a: 203). Sztompka (1999) determines trust as a stake in relation to future unforeseen actions of others. Fukuyama (2000: 4) notes that trust is a characteristic of the system, and argues that "the well-being of the nation, as well as its ability to compete, is conditioned by a unique cultural characteristic: the level of trust in society" (Fukuyama, 1995: 33). He introduces the concept of the radius of trust and argues that high level of trust in society is a major factor for its tendency toward democracy (see: Fukuyama, 2000: 4-5).

\section{TYPES OF TRUST}

There are many different levels and taxonomies of trust. Theoretically, there are several ways of categorizing trust. The most common types are political trust and social trust (see Figure 1) and they should not be viewed as the same thing (Putnam, 2000: 137).

Social trust (horizontal, interpersonal) is defined as trust in other people; it is essential for the cultivation of soil for stability and peaceful relations, which are the basis for productive human cooperation (Newton, 2001b: 3-7). Social trust is further divided into generalized trust (trust in people in general) and particularized trust (in groups and individuals who we are in contact with).

Political (public) trust is the ability of any government to govern effectively and efficiently without the use of coercion. In short, political trust is "individual's expectation that a political actor will act in his interest" (Bauer, Fatke, 2014: 51) Political trust is further divided into: trust in political institutions (e.g. parliament and governments) and trust in political operators (e.g. the president, political authorities and other political actors). Enhancing the legitimacy of the system, political trust is a key factor for stability and effectiveness of democracy. 


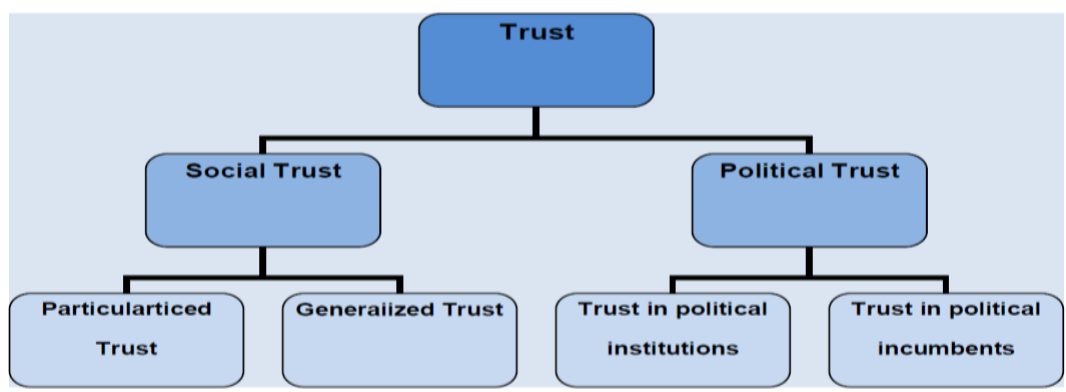

Fig. 1 Categories of trust

Source: Soithong, 2011: 31

Notably, there are five fundamental practices that can ensure trust in a democratic system: (1) communication between citizens to define public goals; (2) tolerance and acceptance of pluralism; (3) consensus on democratic procedures; (4) civic awareness among the actors competing for different purposes; and (5) citizen participation in governing organizations (Carreira, et al., 2016: 6).

\section{TRUST AS A FACTOR AND DETERMINANT OF DEMOCRACY}

On the one hand, trust should be seen as a prerequisite for a democratic process while, on the other, trust is a result of democratic rule (Maldini, 2008: 186). Camaj (2014: 187) finds that trust directly affects both the regime's survival and its effective functioning by influencing perceptions about the quality of the democratic regime and political involvement. In examining the relationship between democracy and trust, Inglehart (1999: 97) distinguished three important aspects of democracy: (1) its long-term stability; (2) the level of democracy at given points in time; and (3) short-term changes in levels of democracy.

A distinction between the various levels of political support is helpful for the debate about the relationship between democracy and trust. Dalton (1999: 10) also noted that it is essential to distinguish between five objects of political support (support for democracy) and two types of political beliefs (Table 1).

Table 1 Levels of Political Support (Support for Democracy)

\begin{tabular}{|c|c|c|}
\hline Level of Analysis & Affective Orientation & Instrumental Evaluations \\
\hline \multirow[t]{2}{*}{ Community } & National pride & Best nation to live \\
\hline & National identity & \\
\hline Regime: Principles & Democratic values & Democracy best form of government \\
\hline \multirow[t]{2}{*}{ Regime: Performance } & Participatory norms & Evaluation of rights \\
\hline & Political rights & Satisfaction with democratic process \\
\hline \multirow[t]{4}{*}{ Regime: Political } & Institutional expectations & Performance judgement \\
\hline & Support party government & Trust in institutions \\
\hline & Output expectations & Trust party system \\
\hline & & Trust bureaucracy \\
\hline \multirow[t]{2}{*}{ Authorities } & $\begin{array}{l}\text { Feelings towards political } \\
\text { leaders }\end{array}$ & Evaluations of politicians \\
\hline & General support & Specific support \\
\hline
\end{tabular}


According to Neo-Tocquevillians, both interpersonal and institutional trust is a building block of a functioning democracy and an inevitable element of civilised social and political life. Trust is vital to the lifeblood of democracy. Actually, the real question is: what kinds of trust are good for democracy? "Particularized trust tends to be attached to the kinds of group identities that are solidified against outsiders, which in turn increases factionalization and decreases chances that conflicts can be negotiated by democratic means..... Generalized trust, on the other hand, is connected to a number of dispositions that underwrite democratic culture, including tolerance for pluralism and criticism" (Warren, 1999a: 9).

Generalized trust is a vital component of democratic transition, given the fact that it increases the sense of empathy towards others and raises the level of tolerance, and thus resolves the collective action dilemma. Trustful people are more likely to volunteer in associations, which is an indicator of the intensity of social participation. In addition to enhancing connectivity through social networks and mobilizing common resources, generalized trust also affects the level of political participation. "Horizontally, generalized trust is an "attitudinal glue" that in a democracy uniquely requires citizens to accept one's fellow citizens as equal participants in the political process" (Abramson, 2017: 3). According to Jamal and Nooruddin (2010: 45), generalized trust is important for democracies because it enhances communal ties, norms of reciprocity, and collective action among the populace. The close relationship between interpersonal trust and vitality of democracy is well documented by a number of studies (Almond, Verba, 1963; Inglehart, 1990, 1999; Putnam, 1993, 2000; Newton, 2001a, 2001b; Muller, Seligson, 1994: 647; Zmerli, Newton, 2008).

Political trust is not only an indicator of the quality of democracy; it is also crucial for the process of democratic governance given that the legitimacy of representative democracy essentially defines the political attitudes of citizens towards institutions and politicians. If citizens believe in the political system and politicians, this will guarantee the functioning of democracy. Satisfaction with democracy and trust in political institutions are strongly determined by factors such as: personal socio-economic position, evaluation of the economic situation, trust in other members of society, political efficiency, education, political knowledge, and political authoritarianism (Henjak, 2017: 352). For example, Bauer (2018) explores the causal link between unemployment and political assessments (i.e. trust in government and satisfaction with democracy), based on the data panel for two different European countries: Switzerland and the Netherlands. The main finding is that unemployment negatively affects different aspects of individual lives (Bauer, 2018: 3-7).

Political trust is an important indicator of political legitimacy, which is needed for a democracy to be stable and effective. Moreover, this kind of trust is crucial for the representative relationship as an important component of most democratic regimes. The relevance of institutional trust for democracy is reflected in the following: (1) it provides citizen support for the necessary political and economic reforms; (2) it creates conditions for reaching compromise and consensus; (3) it increases the likelihood of rejecting nondemocratic alternatives and speeding up democratic consolidation; (4) it imposes itself as "creator of collective power"; (5) it strengthens the capacity of the system in maintaining and improving prosperity, increasing the efficiency of governments by strengthening the links between citizens and elected institutions that represent them; (6) it encourages political participation, civil rights activism and civil engagement: and (7) it opens space for politicians to pull unpopular moves within reform measures, which is particularly evident in times of crisis. Political trust is equaly important for the stability of established democracy 
as well as for new/flawed democracy, hybride regime or authoritarian regime. Trust in institutions is a basic feature of modern democracies and plays a key role in guaranteeing social, economic and political stability (Bonasiaa, Rita Canale, Liotti, Spagnolo, 2016: 4). Public support for democracy largly rests on whether political institutions work to satisfy people's expectations (Ching-Hsing, 2015: 9). "Since we are talking about politics and dialectics of trust and democracy, we should not fear popular mistrust of a particular administration as if it were a threat to democracy ("throw the bums out"). However, loss of general trust in the rules of the game, the good faith of the other side, or the fairness and competence of government is a more serious matter" (Abramson, 2017: 2).

Here, it is worth mentioned that there are also opinions according to which permanent distrust in the political system (institutionalized political distrust) may produce the necessary healthy skepticism to keep democracy more effective. This is paradox of democracy: institutionalising distrust for the sake of trust (Sztompka, 1997: 16). "There are two caveats though. First, empirical research has indicated a continuous growth in mistrust that has reached extremely high level, so as to represent a threat for democracy functioning. Second, there is a need for political institutions to adapt to the increasing levels of mistrust" (della Porta, 2012: 42). Notably, too much blind citizens' confidence in political institutions and/or in political leaders can be problematic for democracy just as too little trust, particularly bearing in mind that excessive trust develops political apathy and strengthens the loss of civic caution and control of power, which can eventually undermine democracy.

Examining the level and nature of trust, as a determinant of social practice, has significant implications in terms of democratic transition in post-communist Europe, as a phase of "democratic development" which is characterized by a "trust deficit" (as a result of the legacy of the former authoritarian regime). This is because (generalized and political) trust in CEE countries can be imposed as one of the unavoidable factors of their further movement towards market economy and democratic consolidation. Former communist countries are distinguished by the high level of structural social capital (informal networks), which is primarily a consequence of the dominance of traditional social relations and inefficient state institutions; at the same time, these countries record low levels of cognitive social capital in the form of a low level of interpersonal and institutional trust (Gaidyte, 2013: 5-8). In order to consider the consequences of confidence for regime support, democratic values and political involvement in Russia, Mishler and Rose (2005: 10571074) test the empirical validity of cultural and institutional theories, whereby quantitative analysis has unequivocally confirmed the argument of cultural theories according to which institutional trust encourages political involvement and contributes to public support for democratic ideals.

Instead of being constituted as a social and cultural norm in post-communist societies, generalized social trust is "strategically egoistic" and atomized (in-group, specific ("thick") trust) societal trust due to what his role is absent as a collective resource of political action When it comes to political trust, a phenomenon known as a "post-honeymoon" effect emerged in most of the post-communist countries; namely, as economic and political reforms were introduced, political trust declined significantly, and was then stabilized at the level lower than in the early stages of transition. The fall in trust in political institutions in post-communist countries is the result of phenomena such as: endemic corruption at all levels, economic problems and social inequality, ethnic conflicts, bad legal framework, transition injustice and grey economy (Gaidyte, 2013: 5-8). 
Based on the Economist Intelligence Unit's Democracy Index 2016, Figure 2 shows a weak or insignificant correlation between a level of general trust and the level of democracy in the selected transition countries (10 CEE countries: the Visegrad group countries (Hungary, Poland, Czech Republic, Slovakia), Baltics states (Estonia, Lithuania, Latvia), Slovenia, Bulgaria, Romania and Republic of Serbia).

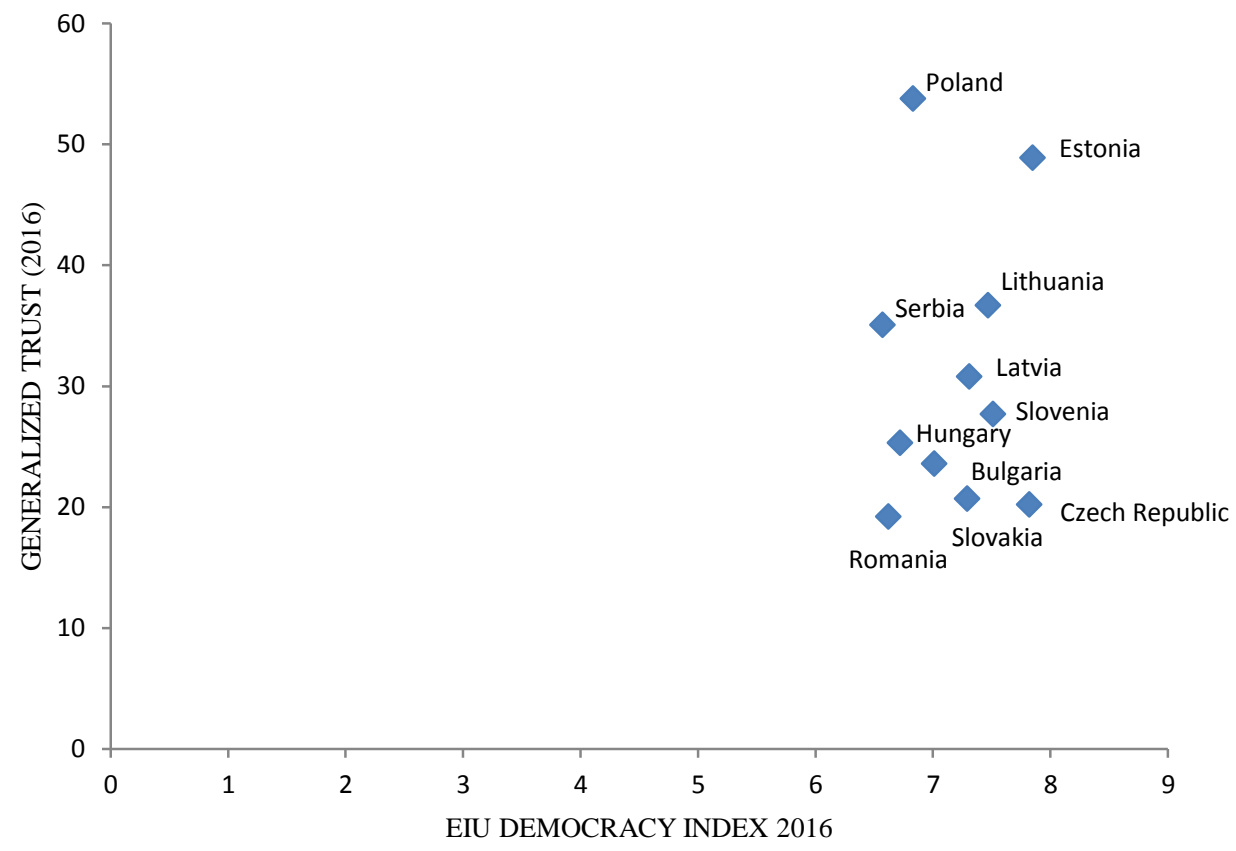

Fig. 2 Democracy and Trust in People

Note: Generalized trust is the average percentage who said "most people can be trusted" in each country. The EIU Democracy index, as a measure of democracy, is on the scale of 0 to 10. The index values are used to place countries within one of four types of regime: 1). Full democracies: scores of 8-10;2). Flawed democracies: score of 6 to 7.9; 3). Hybrid regimes: scores of 4 to 5.9 ; 4) Authoritarian regimes: scores below 4.

Source: EBRD (2016) Life in Transition III and The Economist Intelligence Unit's Democracy Index 2016

Finally, according to Uslaner (2000: 20) economic inequality is the single biggest barrier to interpersonal trust in democratic nations. So, it is possible to increase trust indirectly by encouraging policies that reduce economic inequality (Uslaner, 2003: 15). Authoritarian societies destroy trust, but democratizing a regime will not automatically lead to higher levels of trust ${ }^{1}$. Thanks to the democratic regime, the preconditions for strengthening generalized trust and expanding social networks are being created (Uslaner, 1999: 121-151). Democracy is consistent with high and low levels of generalized trust ${ }^{2}$.

\footnotetext{
${ }^{1}$ See: Uslaner, E.M., "Trust and Economic Growth in the Knowledge Society", available at: http://www.esri.go. jp/en/workshop/030325/030325date2-e.pdf ) POWERPOINT PRESENTATION

${ }^{2}$ See: Uslaner, E.M., "Trust and Economic Growth in the Knowledge Society", available at: http://www.esri.go. jp/en/workshop/030325/030325date2-e.pdf) POWERPOINT PRESENTATION
} 
Decline of trust is a feature of many countries regardless of the diverse institutional structures, historical legacies and cultural underpinnings (Blind, 2006: 14). The key consequence of the fall in political trust is the undermining of the pillars of representative democracy, manifested by the increasingly low voter turnout and low level of participation. As a kind of response to the extremely low levels of political trust, deliberative democracy is put in place that could help establish a new general belief that "we're all in it together," as moral forms of politics where no group is disproportionate in advantages or disadvantages due to discretionary state actions. In the absence of more significant trust, processes of democratization may even lead to disaster, as can be clearly seen on the case with the flood of refugees from civil wars and nameless atrocities in Afghanistan, Iraq, Libya and Syria.

\section{CONCLUSION}

There are different theories about the relationship between democracy and trust. Abramson (2017: 17) believe that trust and distrust ideally play complementary roles in a democracy. It is well known that democracy, as a system of decentralized action, generates the occurrence of uncertainty; on the other hand, generalized trust through risk reduction amortizes various types of day-to-day uncertainties (Volchenko, Shirokanova, 2017: 10).

When talking about the trajectory of trust in new democracies, the essential challenge of democratic transformation and consolidation of post-communist societies in the upcoming period would be remodeling institutional trust by improving government performance and breaking the vicious circle of particularized, narrow-radius trust and its transformation into far-reaching, flexible generalized trust. In order to move from partial democracy into a fully-fledged, consolidated democracy, new democracies require meritocracy, i.e. responsible and transparent institutions, as a guarantee of security and predictability of social interactions.

"Ultimately, democracy and trust do not need to refer to anything outside of the potentials already embedded in contingent social relations; they do not need metaphysics, nor do they need to rely on unquestioned tradition. Yet they together name and evoke the normative potentials already existing within social relationships for a good society of reflective, self -governing individuals" (Warren, 1999b: 343).

\section{REFERENCES}

Abramson, J., (2017). Trust and Democracy, Knight Commission on Trust, Media, and American Democracy, The Aspen Institute, July 2017, available at: https://www.aspeninstitute.org/programs/communications-andsociety-program/knight-commission-workshop-trust-media-american-democracy-2/ (accessed 20.4.2018).

Almond, G., Verba, S., (1963). The Civic Culture: Political Attitudes and Democracy in Five Nations, Princeton, NJ: Princeton University Press, available at: https://www.degruyter.com/viewbooktoc/product/ 474670 (accessed 10.2.2018).

Bauer, C.P., Fatke, M., (2014). Direct Democracy and Political Trust: Enhancing Trust, Initiating Distrust-or Both?, Swiss Political Science Review 20(1)., pp. 49-69, doi:10.1111/spsr.12071, available at: https://onlinelibrary.wiley.com/doi/pdf/10.1111/spsr.12071 (accessed 14.3.2018).

Bauer, P.C., (2018). Unemployment, Trust in Government, and Satisfaction with Democracy: An Empirical Investigation, Socius: Sociological Research for a Dynamic World Volume 4: 1-14, https://doi.org/ 10.1177/23780231177505, available at: http://www.asanet.org/sites/default/files/attach/journals/ jan5sociusfeature.pdf (accessed 17.8.2018).

Blind, P.K., (2006). Building Trust in Government in the Twenty-First Century: Review of Literature and Emerging Issues, $7^{\text {th }}$ Global Forum on Reinventing Government Building Trust in Government 26-29 June 
2007, Vienna, Austria, November 2006, available at: http://unpan1.un.org/intradoc/groups/public/ documents/UN/UNPAN025062.pdf (accessed 12.7.2018).

Bonasia, M., Rita Canale, R., Liotti , G., Spagnolo, N., (2016). Trust in Institutions and Economic Indicators in the Eurozone: the Role of the Crisis, Inzinerine Ekonomika-Engineering Economics, 2016, 27(1), pp. 4-12, available at: http://inzeko.ktu.lt/index.php/EE/article/view/12581/7426 (accessed 8.2.2018).

Camaj, L., (2014) Media Use and Political Trust in an Emerging Democracy: Setting the Institutional Trust Agenda in Kosovo, International Journal of Communication 8(2014),, pp. 187-209, available at: http://ijoc.org/index.php/ijoc/article/download/2107/1065 (accessed 2.2..2018).

Carreira, V., Machado, J.R., Vasconcelos, L., (2016). Engaging Citizen Participation-A Result of Trusting Governmental Institutions and Politicians in the Portuguese Democracy, Social Sciences, Vol. 5., No. 40., pp. 1-11, available at: https://ideas.repec.org/a/gam/jscscx/v5y2016i3p40-d75393.html accessed (15.5.2018).

Ching-Hsing, W., (2015). Social Networks, Interpersonal Trust, and Support for Democracy in East Asia, International Journal of Social Science Studies, Vol.3, No. 2, March 2015, pp. 1-10, at: http://www.academia.edu/11246852/International_Journal_of_Social_Science_Studies_Vol._3_No._2_Mar ch_2015 (accessed 12.4.2018).

Christensen, C.T., Laegreid, P., (2003). Trust in Government - the Significance of Attitudes Towards Democracy, the Public Sector and Public Sector Reforms, Working Paper 7 - 2003, Stein Rokkan Centre for Social Studies Bergen University Research Foundation April 2003, available at: http://cms.uni.no/ media/manual_upload/N07-03-Christensen-Laegreid.pdf (accessed 10.3.2018).

Dalton, R.J., (1999) Political Support in Advanced Industrial Democracies, Pippa Norris (ed) Critical Citizens: Global Support for Democratic Governance 1999 Oxford: Oxford University Press, Chapter 3, available at: https://sites.hks.harvard.edu/fs/pnorris/Acrobat/Dalton.pdf (accessed 14.4.2018).

Della Porta, D., (2012). Critical Trust: Social Movements and Democracy in Times of Crisis, Anno II, Numero 4/Dicembre 2012, pp. 33-44 DOI: 10.1400/205655, available at: http://fupress.net/index.php/cambio/ article/viewFile/19432/17980 (accessed 2.2..2018)

Fukuyama, F., (1995). Trust: The Social Virtues and the Creation of Prosperity, New York: Simon and Schuster, available at: https://www.amazon.com/Trust-Social-Virtues-Creation-Prosperity/dp/0684825252 (accessed 15.1..2018).

Fukuyama, F., (2000). Social Capital and Civil Society, International Monetary Fund Working Paper WP/00/74, available at: https://www.imf.org/external/pubs/ft/wp/2000/wp0074.pdf (accessed 12.2.2018).

Gaidyte, T., (2013). Trust in Mature and Post-communist Democracies, Sociopedia.isa, pp.1-13, DOI: 10.1177/205684601364, available at: http://www.sagepub.net/isa/resources/pdf/Trust.pdf (accessed 15.3.2018).

Henjak, A., (2017). Institutional Trust and Democracy Satisfaction in Croatia: Partisanship - versus OutcomeDriven Evaluations, HKJU-CCPA, 17(3), 343-364, available at: file:///F:/Documents/Downloads/henjak\% 20(1).pdf (accessed 10.7.2018)

Inglehart, R., (1990). Culture Shift in Advanced Industrial Society, Princeton University Press, Princeton, available at: https://press.princeton.edu/titles/4514.html (accessed 12.2.2018).

Inglehart, R., (1999). Trust, Well-Being and Democracy/ In Warren, M.E. (ed), Democracy and Trust/.Cambridge: Cambridge University Press, pp. 88-121, available at: http://www.scirp.org/(S (vtj3fa45qm1ean45vvffcz55))/reference/ReferencesPapers.aspx?ReferenceID=1954831, （accessed 15.4.2018).

Jamal, A., Nooruddin, I., (2010). The Democratic Utility of Trust: A Cross-National Analysis, The Journal of Politics, Vol. 72., No. 1., (Jan., 2010), pp. 45-59, available at: https://www.journals.uchicago.edu/doi/abs/ 10.1017/S0022381609990466 (accessed 18.6.2018).

Leković, V., (2012). Poverenje kao institucionalni faktor ekonomske uspešnosti (Trust as an institutional factor of economic performance), Ekonomski horizonti, Maj-Avgust 2012, Godište XIV, Sveska 2, 2012, pp. 6375, available at: http://www.horizonti.ekfak.kg.ac.rs/sites/default/files/Casopis/2012_2/SR/Vlastimir_ Lekovic.pdf (accessed 14.4.2018).

EBRD (2016), Life in Transition Survey III, from http://www.ebrd.com/what-we-do/economic-research-anddata/data/lits.html, (accessed 12. 3.2018).

Maldini, P., (2008). Političko povjerenje i demokratska konsolidacija (Political trust and democratic consolidation), Politička misao, Vol. XLV, No. 1, pp. 179-199, available at: https://hrcak.srce.hr/24906 (accessed 12.3.2018).

Mishler, W., Rose, R., (2005). What are the Political Consequences of Trust: A Test of Cultural and Institutional theories in Russia, Comparative Political Studies, 38(9)., pp. 1050-78, available at: http://www.u.arizona.edu/ mishler/CPS278419.pdf, DOI: 10.1177/0010414005278419 (accesed 1.6.2018).

Muller, E.N., Seligson, M.A., (1994). Civic Culture and Democracy: The Question of Causal Relationships, American Political Science Review, 88(3), pp. 635-652, available at: https://www.cambridge.org/core/ 
journals/american-political-science review/issue/B5647D8299B6C1D1A014436AC4CACADD (accessed, 22.4..2018).

Newton, K., (2001a). Trust, Social Capital, Civil Society, and Democracy, International Political Science Review, 22(2)., 2001, pp. 201-214, available at: http://www.lead.colmex.mx/docs/s4/02_sociedad\% 20civil\%20y\%20ONG/NEWTON_trust\%20social\%20capital\%20civil\%20society.pdf_ (accessed 15.4.2018).

Newton, K., (2001b). Social trust and political disaffection: Social capital and democracy. Paper prepared for the EURESCO Conference on Social Capital: Interdisciplinary Perspectives, Exeter, 15-20 September 2001, available at: http://citeseerx.ist.psu.edu/viewdoc/download?doi=10.1.1.452.8901\&rep=rep1\&type= pdf (accessed 14.3.2018).

Newton, K., (2005). Support for democracy: Social capital, civil society and political performance, WZB Discussion Paper, No. SP IV 2005-402, Wissenschaftszentrum Berlin für Sozialforschung (WZB), Berlin, available at: http://hdl.handle.net/10419/49609 (accessed 12.12.2018).

Putnam, R., (1993). Making Democracy Work: Civic Traditions in Modern Italy, Princeton, NJ: Princeton University Press.

Putnam, R., (2000). Bowling Alone: Collapse and Revival of American Community, New York: Simon \& Schuster.

Seyd, B., (2016). How Should We Measure Political Trust?, Paper for PSA annual conference, Brighton, $21^{\text {st }}$ $23^{\text {rd }}$, March 2016, available at: https://www.psa.ac.uk/sites/default/files/conference/papers/2016/Paper.v2. pdf (accessed 7.7..2018).

Soithong, W., (2011). Social Capital, People,s Political Participation and Institutional Performance of Local Government in the North of Thailand, Doctoral dissertation, Faculty of Humanities and Social Sciences University of Adelaide, Australia, available at: https://digital.library.adelaide.edu.au/dspace/bitstream/ 2440/70109/8/02whole.pdf (accessed 12.2.2018).

Swedberg, R., (2006). Načela ekonomske sociologije (Principles of Economic Sociology), MATE: Zagrebačka škola ekonomije i menadžmenta.

Sztompka, P., (1997). Trust, Distrust and the Paradox of Democracy, WZB Discussion Paper, No. P 97-003, available at: https://www.econstor.eu/bitstream/10419/50255/1/239015150.pdf (accessed 12.5.2018).

Sztompka, P., (1999). Trust: a sociological theory, Cambridge University Press, Cambridge, available at: https://www.amazon.com/Trust-Sociological-Cambridge-Cultural-Studies/dp/0521591449 (accessed 12.4.2018).

The Economist Intelligence Unit's Democracy Index 2016, available at: http://felipesahagun.es/wpcontent/uploads/2017/01/Democracy-Index-2016.pdf (accessed 11.3.2018).

Uslaner, E.M., (2000). Trust, Democracy, and Governance. Prepared for the European Consortium for Political Research (ECPR) Workshop 13 on Voluntary Associations, Social Capital and Interest Mediation: Forging the Link, April, 2000, Copenhagen, Denmark, available at: https://ecpr.eu/Filestore/PaperProposal/ f36cd18b-66f3-4ebf-98ce-46e52fb1548e.pdf (accessed 8.3.2018).

Uslaner, E.M., (2003). Trust in the Knowledge Society. Prepared for the Conference on Social Capital, Cabinet of the Government of Japan, March 24-25, Tokyo, Japan, available at: https://www.researchgate.net/ publication/228859607_Trust_in_the_Knowledge_Society (accessed 11.3.2018).

Uslaner, E.M., "Trust and Economic Growth in the Knowledge Society", available at: http://www.esri.go.jp/ en/workshop/030325/030325date2-e.pdf., POWERPOINT PRESENTATION.

Uslaner. E.M., (1999). Democracy and Social Capital/ In, Warren, M.E. (ed), Democracy and Trust/ .Cambridge: Cambridge University Press, pp. 121-151.

Volchenko, O., Shirokanova, A., (2017). Generalized Trust and Media Consumption in Democratic and Nondemocratic Societies, Basic Research Program Working Papers Series: Sociology WP BRP 76/SOC/2017, available at: https://www.hse.ru/data/2017/11/20/1161004691/76SOC2017\%20\%D0\% B8\%D1\%82\%D0\%BE\%D0\%B3.pdf

Warren, M.E., et al., (1999). Democracy and Trust, Cambridge: Cambridge University Press.

Warren, M.E., (1999a). Introduction/In: Warren, M.E., (ed.). Democracy and Trust, Cambridge: Cambridge University Press, pp. 1-22.

Warren, M.E., (1999b). Democratic Theory and Trust/In Warren, M.E., (ed.). Democracy and Trust, Cambridge: Cambridge University Press, pp. 310-346.

Zmerli, S., Newton, K., (2008). Social Trust and Attitudes Toward Democracy, Public Opinion Quarterly, Vol. 72., No. 4, 2008, pp. 706-724, available at: https://www.researchgate.net/publication/31138312_ Social_Trust_and_Attitudes_Toward_Democracy (accessed 12.3.2018). 


\section{ANALIZA POVERENJA \\ KAO ELEMENTA PODRŠKE DEMOKRATSKIM PROCESIMA}

Smanjenje poverenja jedan je od centralnih problema u modernoj politici. Poverenje opada $u$ kolektivnim akcionim aranžmanima. Poverenje je jedno od "velikih pitanja", $i$ "jedna od normalnih obaveza političkog života". Ugrađeno unutar njih, poverenje je fundamentalno pitanje politike $i$ demokratske teorije. U ovom članku želim da diskutujem o različitim konceptima poverenja (i njihovim odnosima sa demokratijom). Rad se nastavlja na sledeći način. U prvom delu, daje se konceptualna $i$ teorijska definicija poverenja. U drugom delu ukazuje se na jednu od osnovnih podela poverenja koja je prisutna u litaraturi. Konačno, u trećem delu, ukazuje se na odnos između poverenja i demokratije i nudi odgovarajuća argumentacija.

Ključne reči: poverenje, demokratija, generalizovano poverenje, poverenje u političke institucije 